\title{
Landsat imagery applications to identify vegetation recovery from acidification in mountain catchments
}

\author{
Josef Ǩ̌EČEK and VLASTISLAV KRČMÁ̌̌̃ ${ }^{1}$
}

\begin{abstract}
In the 1980s, headwater catchments of the Jizera Mountains (Czech Republic) were degradated by the extreme acid atmospheric deposition, die-back of spruce plantations (Picea abies), and commercial forestry practices. The aim of this study is to evaluate long-term changes in the vegetation canopy within two catchments of drinking water reservoirs Josefův Důl and Souš, using the Landsat imagery archive, 1984-2010. The ground-based evidence of canopy characteristics was carried out in the Jizerka experimental basin on plots $30 \times 30 \mathrm{~m}$. The supervised classification of multi-band raster images was found effective to describe long-term changes in the canopy of investigated catchments. The NDVI index can well identify succession of herbaceous communities after the clear-cut. However, NDVI values were not sensitive to detect changes in the canopy structure of dense spruce stands where the horizontal canopy density exceeds 30 percent.
\end{abstract}

Keywords: forested mountain watershed, canopy density, acid atmospheric deposition, Landsat imagery, normalised difference vegetation index

\section{Introduction}

Pike, R.G. et al. (2010) referred to a highly significant role of forest canopy in the runoff genesis, particularly in a mountain catchment. Methods of remote sensing and image interpretation focused on indicating the forest canopy have been used in many projects worldwide (Lillesand, T. and Kiefer, R.W. 1987; Wolter, P.T. et al. 1995; Burroughs, P.A. and McDonnell, R.A. 1998). Since 1972 Landsat satellites have continuously and consistently archived images of Earth, and the Landsat Programme provides the longest continuous space-based record of Earth's land with applications in many types of environmental studies (NASA 2014). Applications of the Landsat imagery are now supported by NASA (2014) and the Global Land Cover Facility (GLCF, 2014), free to download.
The Jizera Mountains (Czech Republic, $50^{\circ} 40^{\prime}-50^{\circ} 52^{\prime} \mathrm{N}, 15^{\circ} 08^{\prime}-15^{\circ} 24^{\prime} \mathrm{E}$, humid temperate zone) is part of the so-called "Black Triangle", the epicentre of acid atmospheric deposition in Europe (Figure 1).

The region includes a $200 \mathrm{~km}^{2}$ forest plateau above $800 \mathrm{~m}$ elevation with dominant spruce plantations (Picea abies), important particularly for the national water resource recharge. In the 1980s, this area was degraded by acidification, defoliation and die-back of spruce stands, and the commercial forest harvest (Ǩ̌Ě̌EK, J. and HoŘicKÁ, Z. 2010).

The association Junco effusi-Calamagrostietum villosae became a dominant community there, reported by Ǩ̌̌ĚEK, J. et al. (2010). Although the reforestation followed immediately after clear-cut, there was relatively slow progress in the forest stand development because of the competition of invasive grasses and the

\footnotetext{
${ }^{1}$ Department of Hydrology, Czech Technical University in Prague, Thákurova 7, CZ-166 29 Prague 6.

E-mail: josef.krecek@fsv.cvut.cz
} 


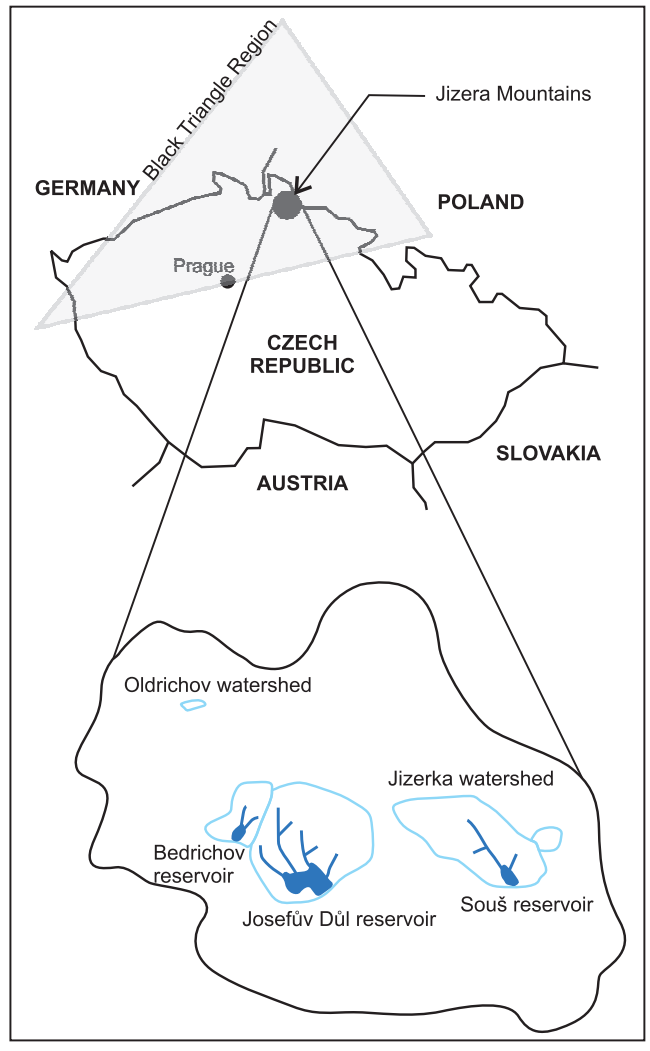

Fig. 1. Focused headwater catchments in the Jizera Mountains

high level of acidification. The aim of this study is to evaluate long-term changes (19842010 ) in the vegetation canopy of three headwater catchments in the Jizera Mountains by analysing the Landsat imagery data, supported by the standard ground survey.

\section{Material and methods}

Three headwater catchments with dominant spruce plantations were analysed in this study: the experimental basin Jizerka (J), and two basins of drinking water reservoirs Josefův Di̊l (JD) and Souš (S). Basic morphological characteristics of the focused catchments are given in Table 1.

From the archive of Landsat imagery, clear-sky images of summer seasons (JuneAugust) were taken into account. This timing corresponds to recommendations of CHEN, J.M. and CinlaR, J. (1996) to avoid an underestimating the herbaceous layer. The normalised difference vegetation index (NDVI) was evaluated, and images classified respecting different types of the vegetation cover. The NDVI index was calculated for the spectral reflectance registered in the visible (red) and near-infrared bands, equation (1) according to Weier, J. and Herring, D. (2000).

$$
N D V I=(N I R-V I S) /(N I R+V I S),
$$

where NIR = near infrared radiation (0.7-1.1 $\mu \mathrm{m}), V I S=$ visible radiation $(0.4-0.7 \mu \mathrm{m})$.

Also the supervised classification of multiband raster images (Landsat 4,5) was employed. For collected samples (representing distinct sample areas of different canopy) the images were classified by the image analyst (NaGI, R. 2011). The estimated canopy classes were used to extrapolate outcomes of the detailed environmental monitoring at the experimental basin $(\mathrm{J})$ to larger catchments of water reservoirs (JD and S).

In the experimental basin $(\mathrm{J})$, groundbased evidence (squares of $30 \times 30 \mathrm{~m}$, corresponding to the Landsat image resolution) of canopy characteristics was carried out annually respecting seasonal patterns of the herbaceous layer (К̌̌̌̌čEK, J. et al. 2010).

The respected canopy classes taking into account by this study included: clear-cut,

Table 1. Characteristics of the basins Jizerka (J), Josefüv Dưl (JD) and Souš (S)

\begin{tabular}{c|c|c|c|c|c}
\hline Basin & Area (A), $\mathrm{km}^{2}$ & $\begin{array}{c}\text { Mean elevation } \\
(\mathrm{E}), \mathrm{m}\end{array}$ & $\begin{array}{c}\text { Mean slope } \\
(\mathrm{S}), \%\end{array}$ & Length (L), km & $\begin{array}{c}\text { Shape index } \\
\mathrm{A} / \mathrm{L}^{2}(-)\end{array}$ \\
\hline J & 1.03 & 927 & 12.00 & 1.14 & 0.79 \\
JD & 19.64 & 834 & 11.90 & 5.49 & 0.65 \\
S & 13.78 & 865 & 14.00 & 5.06 & 0.54 \\
\hline
\end{tabular}


herbaceous vegetation (with Calamagrostis $s p$. dominant), reforested areas (mostly by spruce again) respecting the crown closure limit of 0.3 , and mature spruce stands. This adopted scheme roughly corresponds with the definition of "forest" used by the United Nations Framework Convention on Climate Change (crown closure $>0.1-0.3$ and height $>2-5 \mathrm{~m}$ at maturity) (SASAKI, N. and Putz, F.E. 2009).

\section{Results and discussion}

The distribution of representative canopy clusters in investigated catchments (J, JD

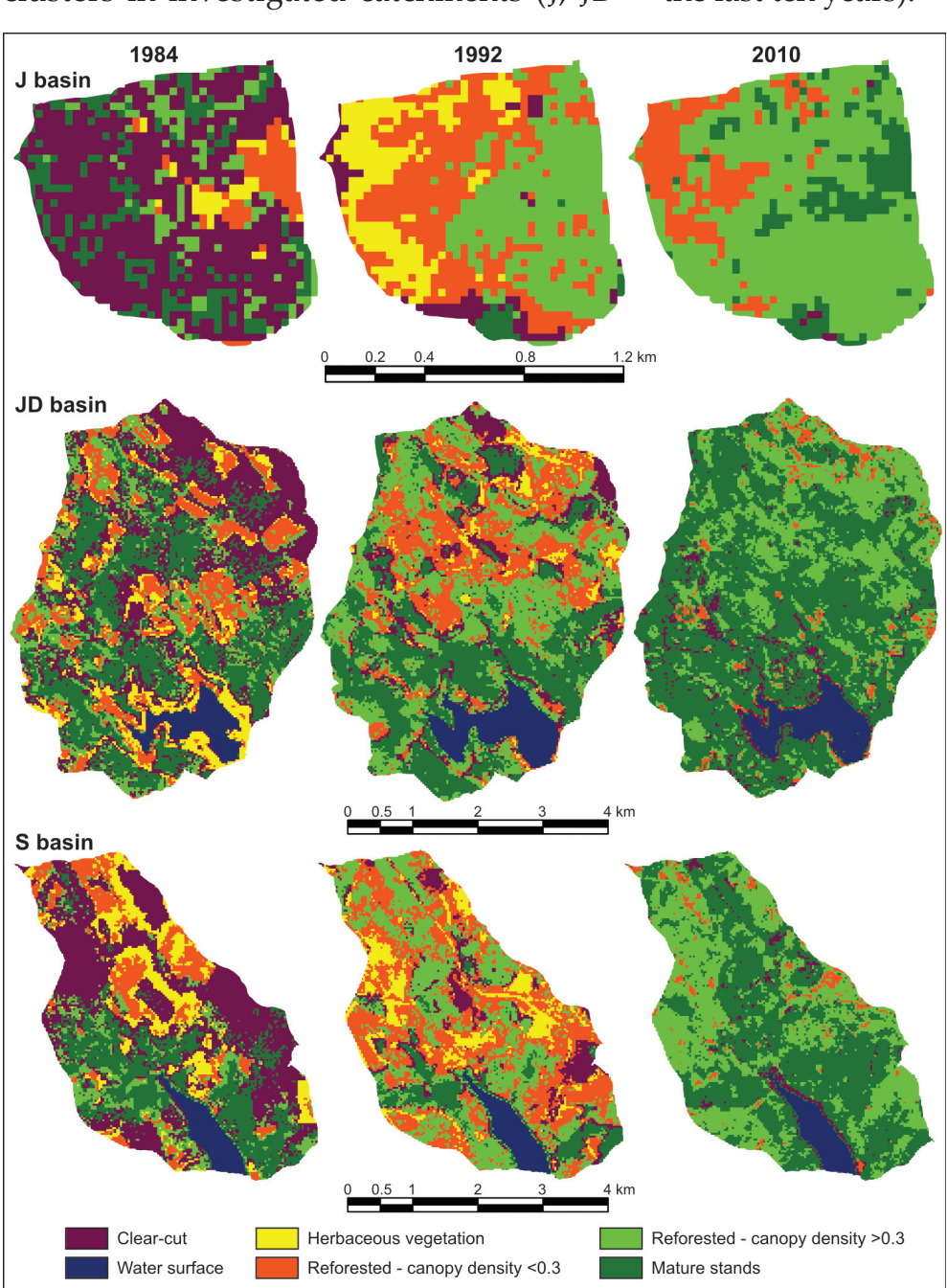

and S) have been shown in Figure 2, and the corresponding percentage of class-evidence within watershed areas have been given in Figure 3 (for time horizons of 1984, 1992, 2002 and 2010).

The analysed changes in vegetation cover show similar trend in all the investigated catchments: high clear-cut evidence (from 30 to $60 \%$ ) in the 1980 s, dominant herbaceous communities in the 1980s and 1990s (included the reforested sites with low crown closure), and intensive recovery of spruce stands in the 2000s (some 20\% increase in stands with crown closure over 0.3 , during the last ten years).

The NDVI index plotted against crown closure (Figure 4) shows a negative relationship between NDVI values and horizontal density of spruce canopy. Estimated NDVI values (0.65-0.76) correspond to the NDVI range of $0.6-0.8$, introduced for temperate forests by WEIER, J. and Herring, D (2000). However, in our study, the grass community shows higher values of NDVI (0.72-0.76) against spruce stands (0.65-0.72). Similar results were reported also by Gamon, J.A. et al. (1995) finding relatively insensitive NDVI values to iden-

Fig. 2. Changed canopy structure at J, JD and S basins 


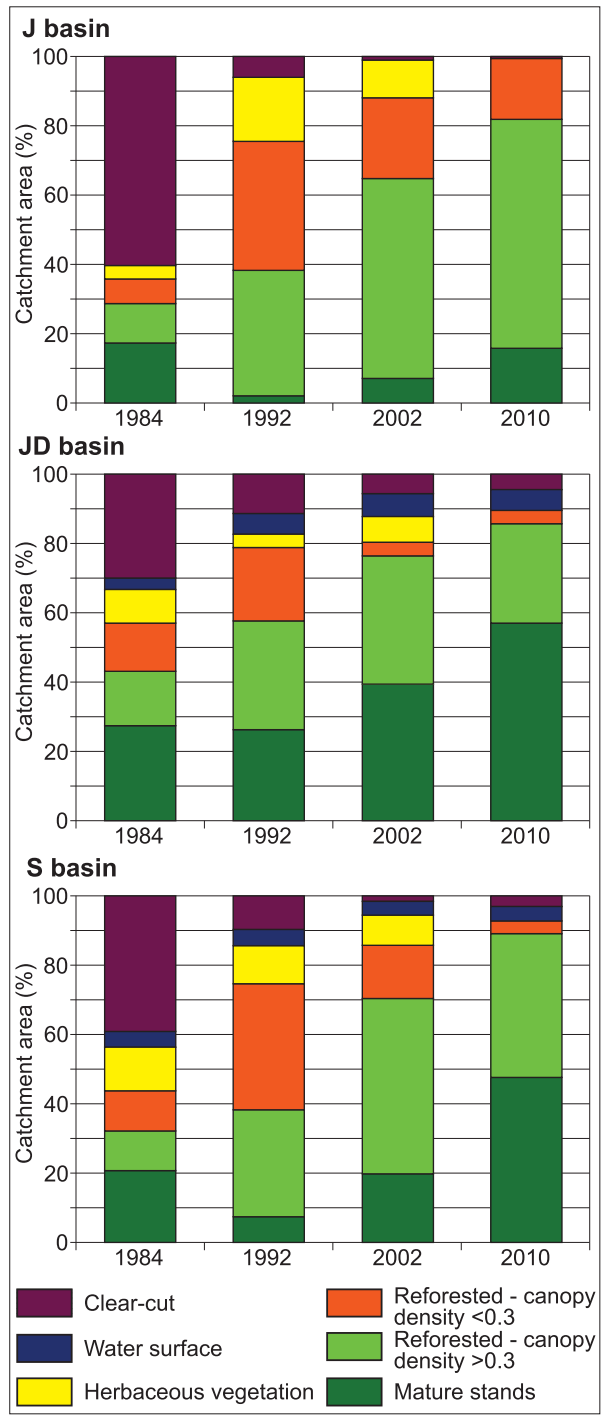

Fig. 3. Changed clear-cut and reforestation in J, JD and $S$ basins

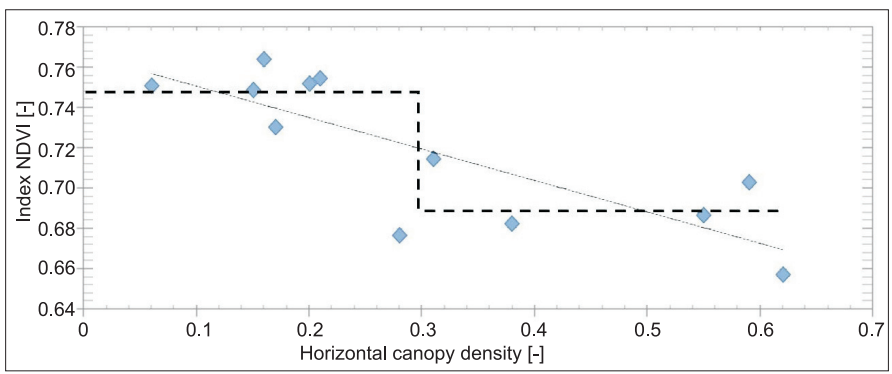

tify changes in the canopy structure of dense shrubs and trees (by leaf area index $L A I>2$ ).

The impact of commercial forest clear-cut on runoff genesis was studied in the experimental basin J since 1982. In 1992, after the harvest of spruce plantations, the drainage network extended from 1.5 to $6.6 \mathrm{~km} / \mathrm{km}^{2}$ (Figure 5). The extended drainage in the basin is a result of skidding the harvested timber by wheeled tractors. Twenty years after, with a spontaneous succession of grasses, and forest recovery, the drainage density was reduced back again to $1.8 \mathrm{~km} / \mathrm{km}^{2}$.

The development of drainage network described in Figure 5 could be interpreted in an extrapolation of drainage network by the clear-cut class occurrence in watersheds JD and S (see Figure 2).

\section{Conclusion}

The supervised classification of multi-band raster images (Landsat 4.5) was found very useful to describe long-term changes in the canopy of mountain watersheds affected by the acid atmospheric deposition. The estimated canopy classes addressed: clear-cut of spruce plantations, dominant herbaceous layer, reforested areas with crown closure below or over $30 \%$, and mature spruce stands (see Figure 3). The identification of clear-cut within a catchment could be used to extrapolate the estimates of drainage network changes, based on the detailed study in the experimental basin (see Figure 5).

The application of NDVI index in this study was limited by the crown closure of spruce (approximately by 0.3) (see Figure 4). The grass
Fig. 4. NDVI index and the horizontal canopy density (estimated by the ground survey) 

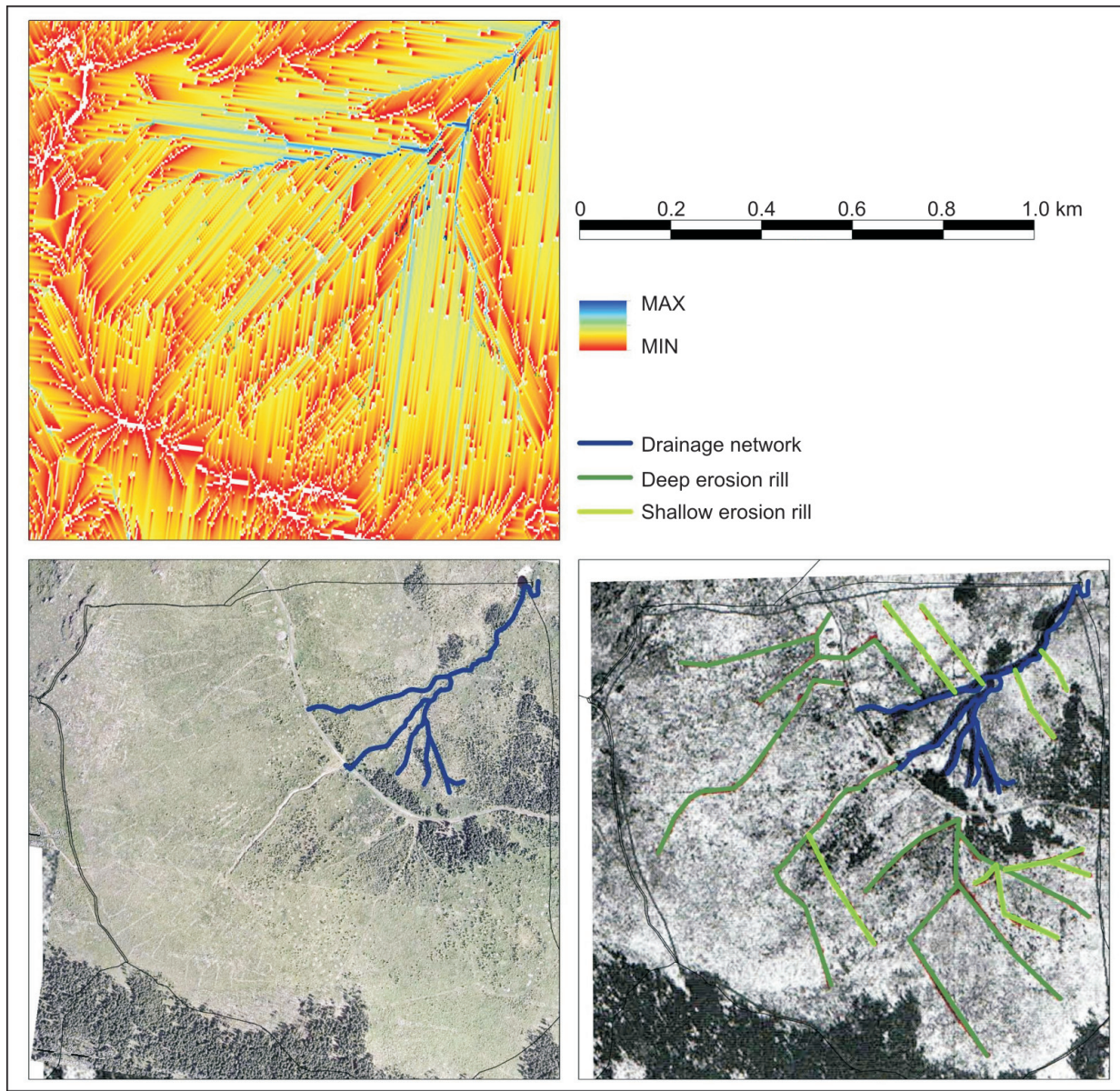

Fig. 5. The risk of concentrated flow from the digital elevation model (on top), and drainage network after the clear-cut of spruce plantations, J basin, 1992 (at the bottom)

community showed higher values of NDVI (0.72-0.76) against spruce stands $(0.65-0.72)$. Therefore, NDVI values are relatively insensitive to identify changes in the canopy structure of dense spruce stands (by horizontal canopy density over 30\%). However, NDVI index can well identify succession of herbaceous layers after the clear-cut. It seems to be important, particularly, in indicating the protection of soil surface and recovery of erosion rills.

Acknowledgements: This research was supported by the Earthwatch Institute (Oxford, UK, Mountain Waters of Bohemia), and by the Czech Technical University in Prague (SGS 14/128/OHK1/2T/11).

\section{REFERENCES}

Burroughs, P.A. and McDonnell, R.A. 1998. Principles of Geographical Information Systems. Oxford, Oxford University Press, 327 p.

Chen, J.M. and Cihlar, J. 1996. Retrieving leaf area index of boreal conifer forests using Landsat TM images. Remote Sensing of Environment 56. 153-162.

Gamon, J.A., Field, Ch.B., Goulden, M.L., Griffin, K.L., Hartley, A.E., Geeske J., Penuelas J. and VALentini, R. 1995. Relationships between NDVI, canopy structure, and photosynthesis in three Californian vegetation types. Ecological Applications 5. 28-41.

GLFC, 2014. Landsat imagery. Global Environmental Facility, http://glcf.umd.edu, accessed on the $24^{\text {th }}$ October 2014. 
Ǩ̌EČEK, J. and HořIcKÁ, Z. 2010. Recovery of headwater catchments and lakes affected by the acid atmospheric deposition. In Integrated watershed management. Eds.: Beнeiм, E. et al. Dordrecht, Springer, 200-207.

Ǩ̌̌čeK, J., Nováková, J. and Hořická, Z. 2010. Ellenberg's indicator in water resources control: the Jizera Mountains, Czech Republic. Ecological Engineering 36. 1112-1117.

Lillesand, T. and Kiefer, R.W. 1987. Remote sensing and image interpretation. Second edition. New York, Wiley, 719 p.

NAGI, R. 2011. Classifying Landsat image services to make a land cover map. ArcGIS Resources, ESRI. http://esri.com/esri/arcgis. Accessed on the $24^{\text {th }}$ October 2014.

NASA, 2014. Landsat science. http://landsat.usgs.gov. Accessed on the $24^{\text {th }}$ October 2014.
Pike, R.G., Redding, T.E., Moore, R.D., Winkler, R.D. and BLADON, K.D. 2010. Compendium of forest hydrology and geomorphology in British Columbia. Land Management Handbook 66. (1-2): 749 p.

SAsaki, N. and Putz, F.E. 2009. Critical need for new definitions of "forest" and "forest degradation" in global climate change agreements. Conservation Letters 2009. 1-7.

WeIER, J. and Herring, D. 2000. Measuring vegetation (NDVI \& EVI). Earth Observatory. http://earthobservatory.nasa.gov, accessed on the $24^{\text {th }}$ October 2014.

Wolter, P.T., Mladenoff, D.J., Host, G.E. and Crow, T.R. 1995. Improved forest classification in the Northern Lake States using multi-temporal Landsat imagery. Photogrammetric Engineering and Remote Sensing 61. 1129-1143. 